\title{
Antibiotic Resistance of Azotobacter Isolated from Mercury-Contaminated Area
}

\author{
Reginawanti Hindersah (corresponding author) \\ Faculty of Agriculture Universitas Padjadjaran, Sumedang 45363, West Java, Indonesia \\ Centre of Excellence "Maluku Corner" Universitas Padjadjaran \\ E-mail: reginawanti@unpad.ac.id
}

Gina Nurhabibah

Graduated from Agrotechnology Undergraduate Program

Faculty of Agriculture Universitas Padjadjaran, Sumedang 45363, West Java, Indonesia

E-mail: nurhabibahg@gmail.com

Priyanka Asmiran

Graduated from Soil Science Master Program, Faculty of Agriculture Universitas Padjadjaran Jalan Raya Bandung Sumedang Km. 21 Jatinangor, Sumedang 45363, Indonesia

Phone/fax 022-7797316, E-mail: priyankaasmiran@gmail.com

Etty Pratiwi

Indonesian Soil Research Institute, Bogor 16114 Indonesia

E-mail: ettypratiwi@yahoo.com

Received: May 26, 2019 Accepted: July 22, 2019 Published: August 1, 2019

doi:10.5296/jas.v7i3.14834 URL: https://doi.org/10.5296/jas.v7i3.14834

\begin{abstract}
Nitrogen-fixing Azotobacter is a renewable source of biofertilizer for plant growth. Increased of antibiotic level in soil due to intensive used manure is believed to induce bacterial sensitivity to antaibiotic. An antibiotic sensitivity test has been carried out to study the inhibition effect of ampicillin, streptomycin, tetracycline and chloramphenicol on Azotobacter isolated from mercury-contaminated taling. The resistance test was performend by using disc plate method in Nitrogen-free Ashby's agar with and without mercury. The results showed that the presence of $20 \mathrm{mg} / \mathrm{L}$ mercury in plate agar totally inhibited
\end{abstract}


Azotobater growth. In the absence of mercury chloride, all isolates showed different sensitivity to antibiotics. Growth of Azotobacter buru1 was only inhibited by tetracycline. Azotobacter buru2 was susceptible to high and low concentration of tetracycline and streptomycin but they were resistance to low concentration of chloramphenicol as well as ampicillin; while Azotobacter bd3a were sensitive to all tested antibiotic. In conclusion, order of Azotobacter resistance to antibiotics in the absence of mercury was Bd3a<Buru2<Buru1. This research have not revealed the resistance of Azotobacter to antibiotic in the presence of mercury.

Keywords: antibiotic, gold-mine tailing, mercury, nitrogen-fixing bacteria

\section{Introduction}

Antibiotics are main chemotherapeutic agents for managing human and animal infectious diseases. Animal manure is believed contribute to increased antibiotic level in soil due to intensive used of antibiotic in animal husbandry. Antibiotics utilized in livestock production are excreted in the feces and therefore transferred to soil when manure is used as organic matter amendments. However, organic matter application in agriculture is necessary for returning nutrients to the soil, providing a satisfied growth medium and nutrient for microbes; and further increasing microbial population as well as quality and productivity of soil (Nakhro and Dkhar, 2010; Masciandaro et al., 2013; Faissal et al., 2017).

Tetracycline is the most resistant antibiotic detected at concentration in excess of $1 \mathrm{mg} / \mathrm{kg}$ in terrestrial environments (Massé et al., 2014; DeVries and Zhang, 2016). Antibiotics influence soil microbe metabolism and promote their antibiotic resistance in soil. Manure containing antibiotic enriched soil antibiotic and induced antibiotic resistance genes (Xie et al., 2018). In healthy soil, beneficial microbial communities are important organisms which affect among others the availability of nitrogen; the essential macro nutrients for plant growth and productivity. Microbial activity in soil reduce inert inorganic $\mathrm{N}_{2}$ gasses through nitrogen fixation to $\mathrm{NH}_{3}$ which further is converted to $\mathrm{NH}_{4}{ }^{+}$and $\mathrm{NH}_{3}{ }^{-}$that uptake by plant roots (DeVries and Zhang, 2016).

Nitrogen fixing Azotobacter is widely used plant growth promoting rhizobacteria (PGPR) in agricultural practice to improve soil fertility and prevent soil degradation. Rhizobacteria Azotobacter is believed develop antibiotic resistance mechanisms which is useful to proliferte in antibiotic-contaminated soil. A gene-antibiotic cassette in A. vinelandii algC mutant JGG1 as well as the wild-type strain ATCC 9046 through blot analysis of total DNA was reported (Gaona et al., 2004). The genome of Gram Negative N-fixing A. chroococcum NCIMB 8003 (ATCC 4412) (Ac-8003) determined that they carry a variety of accessory genes e.g. antibiotic resistance genes (Robson et al., 2015).

Azotobacter also might be used in mercury-contaminated soil bioremediation due to their multiple resistance for certain heavy metal (Abo-Amer et al., 2013; Hindersah et al., 2017; Rizvi and Khan, 2018;). Plants in which rhizosphere colonized by heterotrophic Azotobacter enhanced their tolerance to heavy metal toxicity (Nanda and Abraham, 2011; Sobariu et al., 2017). Amalgamation process in gold mine significantly discharge $\mathrm{Hg}$ to soil; mercury 
concentrations remain elevated in soil and sediment near closed gold mine (Opiso et al., 2018). In Buru Island of Maluku Indonesia, agricultural field near closed gold mine was contaminated by $\mathrm{Hg}$ up to $35 \mathrm{mg} / \mathrm{kg}$ (Hindersah et al., 2018).

Bioremediation is an effective way to reduce available $\mathrm{Hg}$ concentration in soil. Application of metal detoxifying bacteria with plant-beneficial properties is a cost effective and environmental friendly metal bioremediation method (Shinwari et al., 2015). Since microbes are the agents for change mercury availability in soil, the application of organic matter enhance microbial density should be considered. In case of Azotobacter inoculation in bioremediation-bioaugmentation process, we need to apply the antibiotic resistance Azotobacter to ensure their proliferation and activity. The objective of this research was to study the inhibition effect of tetracycline, chloramphenicol, ampicillin and streptomycin on some Azotobacter isolate which is isolated from $\mathrm{Hg}$-contaminated soil.

\section{Material and Method}

\subsection{Azotobacter}

Three isolates of Azotobacter were the collection of Soil Biology Laboratory, Department of Soil Science, Universitas Padjadjaran. Azotobacter buru1 and Azotobacter buru2 have been isolated from rhizosphere of wiregrass (Eleusin indica (L.) Gaertn) grown in mercury-contaminated tailing at closed gold mine of Botak Mountain in Buru District of Maluku Province. Azotobacter bd3a were isolated from gold mine tailing at the same area which contain $100 \mathrm{mg} / \mathrm{kg}$ of mercury. All pure cultures of bacteria were maintained in $\mathrm{N}$-free Asbhy's slant at $4{ }^{\circ} \mathrm{C}$. Liquid culture of each isolates were prepared in nitrogen-free Ashby's broth (10 g mannitol, $0.2 \mathrm{~g} \mathrm{KH}_{2} \mathrm{PO}_{4}, 0.2 \mathrm{~g} \mathrm{MgSO}_{4} .7 \mathrm{H}_{2} \mathrm{O}, 0.2 \mathrm{~g} \mathrm{NaCl}, 0.1 \mathrm{~g} \mathrm{CaCO}_{3}, 10 \mathrm{mg}$ $\mathrm{Na}_{2} \mathrm{MoO}_{4}$, and $1 \mathrm{~L}$ distillated water). The media has been sterilized in autuclave fo 20 minutes at $121{ }^{\circ} \mathrm{C}$ before Azotobacter inoculation.

\subsection{Growth Curve Determination}

Curve growth of three Azotobacter isolates was determined by used of N-free Ashby's broth. A total of $1 \mathrm{~mL}$ of each isolates were poured into $100 \mathrm{~mL}$ of Ashby's broth; the cultures were incubated for eight days at $30{ }^{\circ} \mathrm{C}$ on gyratory shaker at 115 rotations per minute. Bacterial count carried out once a day on Ashby's agar after serial dilution. Plates were incubated for 48 hours at room temperature in order to count clear, convex and slimy Azotobacter colonies. Doubling time was calculated at logarithmic phase by using the formula of Widdel (2010).

\subsection{Antibiotic Sensitivity Test}

The disk diffusion susceptibility method was used for antibiotic sensitivity test (Jorgensen and Ferraro, 2009) which has been well standardized. Sensitivity test has been done to determine the resistance of Azotobacter on several concentration of tetracycline, chloramphenicol, ampicillin and streptomycin. Antibiotic solution of 10, 50, 100, 500 and $1,000 \mathrm{mg} / \mathrm{L}$ were prepared by diluting each antibiotic powder in sterilized distillated water.

One milliliter of liquid culture of each isolates was added to $100 \mathrm{~mL}$ nitrogen-free Ashby's broth in individual Erlenmeyer Flask. After three-day incubation, $1 \mathrm{~mL}$ of culture was spread 
out on the surface of Ashby's agar contaminated with $20 \mathrm{mg} / \mathrm{kg} \mathrm{HgCl} 2$ and on $\mathrm{Hg}$-free agar. The test was performed by dipping paper disc into antibiotic solution and placed onto a plate agar upon which single Azotobacter isolate was growing. Plates were incubated at $30^{\circ} \mathrm{C}$ for $72 \mathrm{~h}$ (based on their curve growth in first experiment) prior to inhibition zone determination around each antibiotic disk. Diameter of halo zone were measured to the nearest millimeter. The main process and sub-processes of the research was summarized in Fig 1.

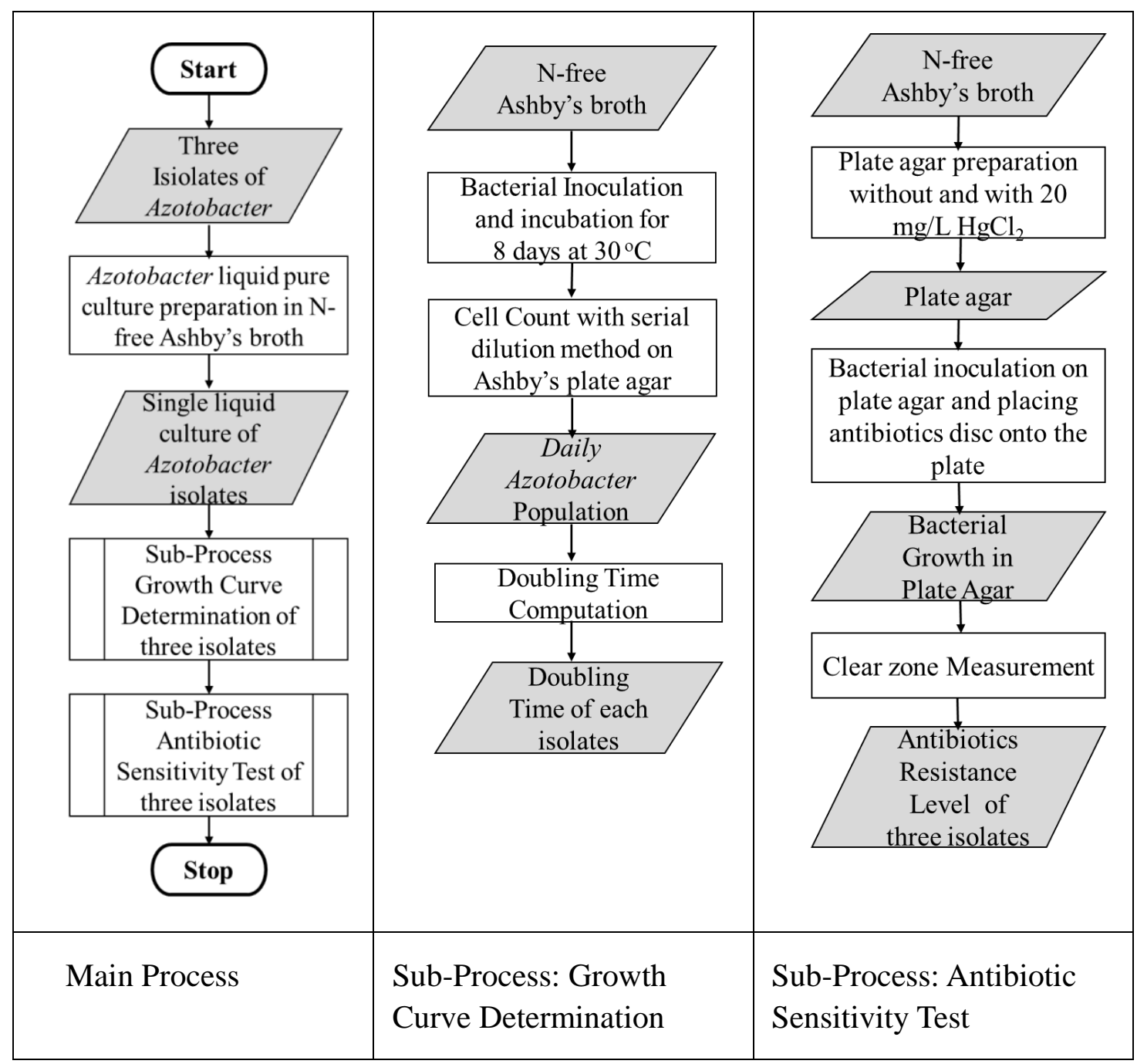

Figure 1. Research method on antibiotic sensitivity test of three isolates of Azotobacter

\section{Results and Discussion}

\subsection{Growth Curve of Azotobacter}

Based on the colony count on plate agar, bacterial population were reduced from day one to day two which showed that all isolated experienced lag phase (Fig 2). This phase is characterized by very little to no bacterial growth. Logarithmic phase was begun at day two and terminated at day 5. The calculation of doubling time (DT) showed that between day 2 and day 5, DT of buru2 is $4.6 \mathrm{~h}$; higher than those of buru1 $(3.9 \mathrm{~h})$. These evidence proofed that cell proliferation of buru2 was slower than those of buru1. The slowest cell multiplication and higher DT was shown by isolates bd3a with DT of 4.9 hours. Doubling 
time of $A$. vinelandii wild type strain was $4 \mathrm{~h}$ in liquid Burk's sucrose medium under diazotrophic conditions was $4 \mathrm{~h}$. The DT was $3 \mathrm{~h}$ and $3.6 \mathrm{~h}$ in the media with $10 \mathrm{mM}$ and 25 $\mathrm{mM} \mathrm{NH}_{4}$ acetate (Mus et al., 2017) reflecting the slower cell division of all isolates.

Bacterial growth curve and DT of each bacterial species or isolate are determined by all the factors that affect bacterial metabolisms and growth, mainly carbon source, nutritional composition, medium acidity, temperature, and aeration. All isolates took two days to adjust with the new environment before they enter logarithmic phase (Fig 2).

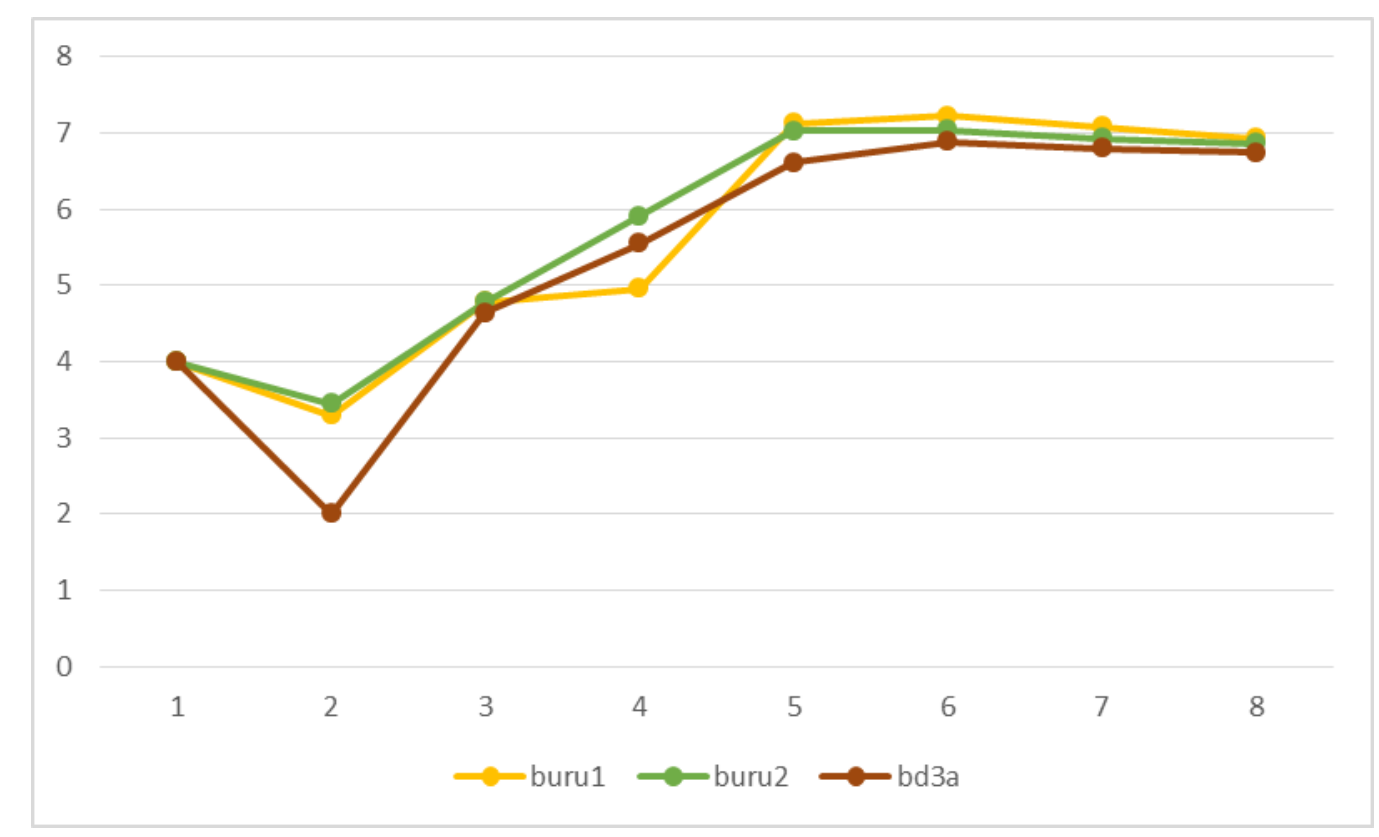

Figure 2. Growth curve of three isolates of Azotobacter on Nitrogen-free Ashby's agar

Population of Azotobacter bd3a was decline sharply during two-day adjustment compared to other isolates. There was no distinct difference in population of all isolate at the end of the experiment. Among the three isolates tested at the end of the incubation period, bd3a cell population was the lowest. However, growth in all three isolates was not significantly differ, at the end of the incubation the population of all isolates was around $10^{7} \mathrm{cfu} / \mathrm{mL}$. If the purpose of the production of a bacterial cell is to obtain inoculant with the highest density, then isolates buru1 was a better one. Based on curve growth, antibiotic sensitivity determination of three Azotobacter isolate was perform up to three days in liquid culture.

\subsection{Antibiotic Resistance Profile of Azotobacter}

Irrespective of generic antibiotic and Azotobacter isolates, Azotobacter colonies failed to grow on plates with $\mathrm{Hg}$ (Fig 3) which showed their susceptibility to $20 \mathrm{mg} / \mathrm{kg}$ of $\mathrm{HgCl}_{2}$. Our previous study demonstrated the resistance of bd3a in Ashby's broth contaminated with 20 $\mathrm{mg} / \mathrm{L} \mathrm{HgCl}$ but buru 1 and buru2 were only resistant to $15 \mathrm{mg} / \mathrm{L} \mathrm{HgCl}$ (Hindersah et al., 2017). In the presence of $\mathrm{Hg} 20 \mathrm{mg} / \mathrm{L}$ on Ashby's agar, bacterial resistance to four generic antibiotics could not be evaluated. In Hg-free agar, bacterial colonies did not appear at 24 hours after incubation but the colonies were visible at day two (Fig 4). In general, inhibition zone depends 


\section{Macrothink Institute ${ }^{T M}$}

on antibiotic concentration resulting higher inhibition zone diameter around disk dipped in higher concentration of antibiotic (Fig 5).

At the second day, growth of bd3a has been inhibited by all concentrations of ampicillin and tetracycline but bd3a was resistant to either $10 \mathrm{mg} / \mathrm{L}$ streptomycin or $50 \mathrm{mg} / \mathrm{L}$ and $200 \mathrm{mg} / \mathrm{kg}$ chloramphenicol. Antibiotic resistance pattern of each Azotobacter isolate at day three in $\mathrm{Hg}$-free media was largely depend on antibiotic and bacterial isolates used in this assay (Table 1 and Table 2). Halo zone in Azotobacter buru1 was only detected around 1,000 and $500 \mathrm{mg} / \mathrm{L}$ tetracycline disks (Table 1). Growth of buru2 was inhibited by higher concentration of tetracycline and ampicillin, and all concentration of streptomycin but they did not sensitive to low concentration of chloramphenicol; meanwhile inhibition zones were determined in most of antibiotic disk on plate agar in which Azotobacter Bd3a grow (Tabel 1 and Table 2).

There was no increased of clear zone diameter on the third day for isolate buru1, buru2 as well bd3a compared to those on the second day, but clear zone diameter around disk dipped in 1,000 and $500 \mathrm{mg} / \mathrm{L}$ tetracycline solution increased mostly doubled (Table 1) showing relatively high sensitivity of Buru 2 on high concentration of tetracycline.


Figure 3. Growth failure of Azotobacter in Ashby's agar contaminated with mercury
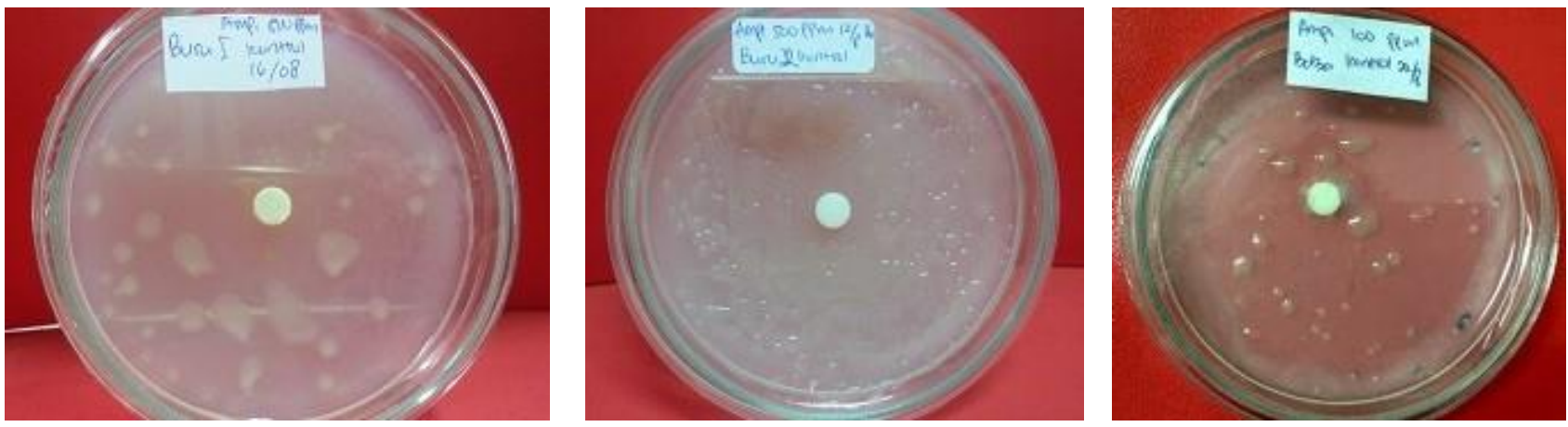

Figure 4. Colony characteristics of Azotobacter Buru1, Buru2 and Bd3a at day two on Ashby's agar without mercury but with antibiotic; colonies of Buru1 and Bd3a were scattered on the plate but Buru2 showed rigorous colony growth on the plate 

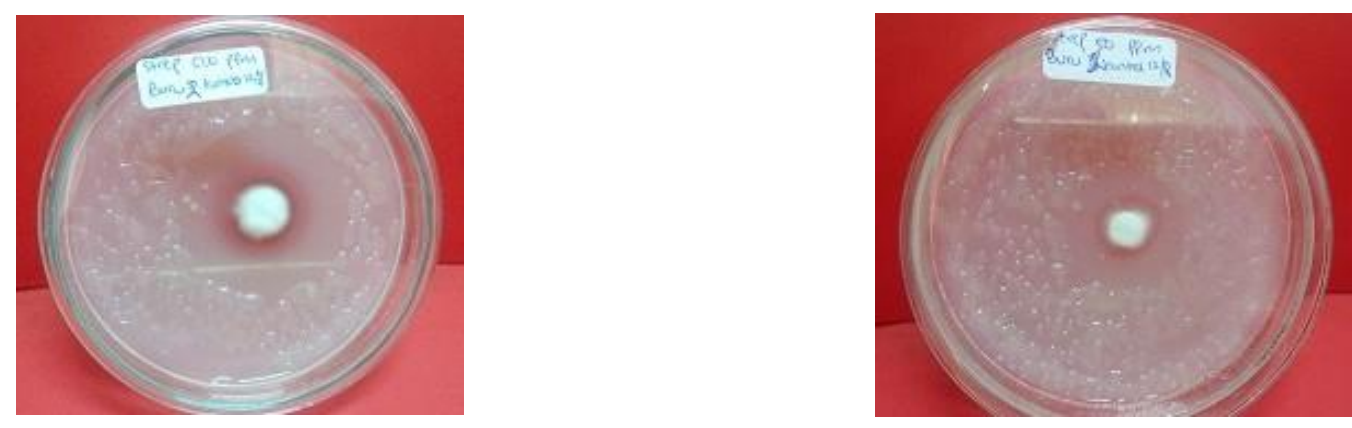

Figure 5. Inhibition zone around $500 \mathrm{mg} / \mathrm{L}$ streptomycin disk on Azotobacter Buru2 growth (left) was larger than around $50 \mathrm{mg} / \mathrm{L}$ streptomycin disk (right)

Table 1. Inhibition zone around tetracycline and chloramphenicol disk in which three isolates of Azotobacter did not grow on Hg-free Ashby's agar

\begin{tabular}{|c|c|c|c|c|c|c|c|c|c|c|c|c|c|}
\hline \multirow{2}{*}{$\begin{array}{l}\text { Azotobacter } \\
\text { Isolates }\end{array}$} & \multirow[t]{2}{*}{ Day } & \multicolumn{6}{|c|}{ Tetracycline $(\mathrm{mg} / \mathrm{L})$} & \multicolumn{6}{|c|}{ Chloramphenicol (mg/L) } \\
\hline & & 1,000 & 500 & 200 & 100 & 50 & 10 & 1,000 & 500 & 200 & 100 & 50 & 10 \\
\hline & & \multicolumn{12}{|c|}{ Inhibition zone $(\mathrm{cm})$} \\
\hline \multirow[t]{2}{*}{ Buru1 } & 2 & 1.6 & 1.5 & - & - & - & - & $*$ & $*$ & $*$ & $*$ & $*$ & $*$ \\
\hline & 3 & 1.6 & 1.5 & - & - & - & - & - & - & - & - & - & - \\
\hline \multirow[t]{2}{*}{ Buru2 } & 2 & 2.2 & 2.0 & 5.0 & 1.8 & $*$ & 1.5 & 1.5 & - & - & - & - & - \\
\hline & 3 & 5.0 & 5.0 & 5.0 & 1.8 & $*$ & 1.5 & 1.5 & - & - & - & - & - \\
\hline \multirow[t]{2}{*}{$\mathrm{Bd} 3 \mathrm{a}$} & 2 & 0.6 & 0.3 & 0.1 & 0.1 & 0.1 & 0.1 & 1.0 & 0.7 & - & 0.3 & - & 0.1 \\
\hline & 3 & 0.6 & 0.4 & 0.1 & 0.1 & 0.1 & 0.1 & 1.0 & 0.8 & - & 0.3 & - & 0.1 \\
\hline
\end{tabular}

*No bacterial growth; - no inhibition on bacterial growth

Tabel 2. Inhibition zone around ampicillin and streptomycin disk in which three isolates of Azotobacter grown on Hg-free Ashby's agar

\begin{tabular}{|c|c|c|c|c|c|c|c|c|c|c|c|c|c|}
\hline \multirow[t]{2}{*}{ Isolates } & \multirow[t]{2}{*}{ Day } & \multicolumn{6}{|c|}{ Ampicillin $(\mathrm{mg} / \mathrm{kg})$} & \multicolumn{6}{|c|}{ Streptomycin $(\mathrm{mg} / \mathrm{kg})$} \\
\hline & & 1,000 & 500 & 200 & 100 & 50 & 10 & 1,000 & 500 & 200 & 100 & 50 & 10 \\
\hline & & \multicolumn{12}{|c|}{ Inhibition zone $(\mathrm{cm})$} \\
\hline \multirow[t]{2}{*}{ Buru1 } & 2 & $*$ & * & * & * & * & $*$ & $*$ & * & $*$ & $*$ & $*$ & * \\
\hline & 3 & - & - & - & - & - & - & - & - & - & - & - & - \\
\hline \multirow[t]{2}{*}{ Buru 2} & 2 & 1.4 & 0.6 & 0.5 & - & - & - & 2.0 & 1.5 & 2.0 & 1.0 & 1.0 & 0.5 \\
\hline & 3 & 1.4 & 0.6 & 0.5 & - & - & - & 2,2 & 2,0 & 1,5 & 1,6 & 1,3 & 1,0 \\
\hline \multirow[t]{2}{*}{$\mathrm{Bd3a}$} & 2 & 1.2 & 1.2 & 0.5 & 0.4 & 0.3 & 0.1 & 1.2 & 0.3 & 0.3 & 0.2 & 0.1 & - \\
\hline & 3 & 1.3 & 1.2 & 0.5 & 0.4 & 0.3 & 0.1 & 1.2 & 0.4 & 0.3 & 0.2 & 0.1 & - \\
\hline
\end{tabular}

*No bacterial growth; - no inhibition on bacterial growth

Bacterial resistance to antibiotics is a natural ability to defend themselves against the harmful effects of antibiotics. Generally, bacterial resistance to antibiotics is performed through three mechanisms; i.e. mutations in porin, inactivation of antibiotics and changes in the active site where the formation of binding of antibiotics by bacteria (Delcour, 2009). The results of this 
assay was similar to the ability of $A$. chroococcum to proliferate in the presence of antibiotic include ampicillin, chloramphenicol, streptomycin and tetracycline (Sindhu et al., 1989; Aung et al., 2016).

Antibiotic resistance of Azotobacter was reported elsewhere. The antibiotic resistance of $A$. chroococcum and $A$. benjerinckii were demonstrated by their growth in agar media with $3 \%$ (w/v) of chloramphenicol (Aung et al., 2016) which verified that this prominent N-fixing PGPR might stand in antibiotic contaminated soil. Azotobacter was more resistance to antibiotics compared to other soil bacteria; Azotobacter count decreased only ten days after soil contamination with ampicilline and streptomycine and 100 days after contamination Azotobacter growth was recovered (Akimenko et al., 2017).

Azotobacter cell wall contain polysaccharides which is well known as exopolysaccharide (EPS); an outer structure of microbial cells associated the nitrogenase protection (Sabra et al., 2000; Prasad et al., 2014; Hindersah et al., 2017). Formation of EPS is also related to bacterial mechanisms avoid heavy metals toxicity through sequester positively charged heavy metal ions (Gupta and Diwan, 2016). For pathogenic bacteria, EPS is also related to their antibiotic sensitivity. Increased capsular EPS production during antibiotic exposure is regulated in response to antibiotic stress in opportunistic pathogen Acinetobacter baumannii (Geisinger and Isbe, 2015). The correlation between EPS and antibiotic resistance for Azotobacter has not studied intensively. All Azotobacter isolate in this experiment synthesize EPS in liquid culture but their EPS production related to antibiotic resistance has not been studied.

The three isolates showed different sensitivity to antibiotic in the absence of Mercury but 20 $\mathrm{mg} / \mathrm{L}$ of $\mathrm{HgCl}$ was too high to maintain cell proliferation in Nitrogen-free Ashby's agar. Mercury might inhibit nitrogenase resulting lack of available nitrogen mainly nitrate; major macronutrient in cell formation and development. Azotobacter proliferation in the presence of mercury has been documented; A. chrooccocum isolated from wheat (Triticum aestivum) rhizospheric soil irrigated with industrial wastewater about 10 years had a highest minimum inhibitory concentration of 200 $\mathrm{mg} / \mathrm{L}$ for $\mathrm{Hg}^{2+}$ (Aleem et al., 2003). More EPS production in the presence of $\mathrm{Hg}$ was reported for certain Azotobacter strain (Rasulov, 2013; Hindersah et al., 2017). Bacterial EPS is a prominent natural material to be integrated in bioremediation of metal-contaminated soil in order to reduce their toxic effect of even its low concentration on food chain.

Profile of antibiotic sensitivity will be an important trait for the selection of Gram negative Azotobacter isolates which might stand in antibiotic contaminated soil. For Gram negative bacteria, antibiotics changed enzyme activity and ability to metabolize different carbon sources, and altered microbial biomass (Cycoń et al., 2019). The majority of antibiotics are not completely metabolized in the bodies of livestock; animal manure amendment on agricultural farm causing antibiotics discharged on soil. Our results determined that Azotobacter isolated from $\mathrm{Hg}$-contaminated area might have also an ability to proliferate in certain antibiotic contaminated environment which is will be important to overcome increased antibiotic problem in soil. 


\section{Conclusion}

In Nitrogen-free Asbhy's broth, generation time from day 2 to day 5 of Azotobacter buru1, buru2 and bd3a were $3.9 \mathrm{~h}, 4.6 \mathrm{~h}$ and $4.9 \mathrm{~h}$ respectively reflecting their slow cell division. All isolates had two-day lag phase in Ashby's broth before entering logarithmic phase during another three days. Cell count of Azotobacter bd3a was decline sharply during lag phase compared two other isolates but no distinct difference in all isolate population at day eights.

The presence of $20 \mathrm{mg} / \mathrm{L}$ mercury chloride in Nitrogen-free Ashby's agar totally ceased Azotobater growth; bacterial colony did not grow on the surface of agar so that their resistance to antibiotic remain uncertain. In the absence of mercury chloride, two isolates showed multiple resistance at least to two kind of antibiotics. Growth of Azotobacter buru 1 was only inhibited by tetracycline showing their resistance to Chloramphenicol, Ampicillin and Streptomycin. Azotobacter buru2 was susceptible to high and low concentration of either streptomycin or Tetracycline but resistance to low concentration of chloramphenicol and tetracycline. Susceptibility for all tested antibiotic was showed by Azotobacter bd3a. Azotobacter resistance profile to antibiotic was clearly demonstrated in agar media without $\mathrm{Hg}$. In conclusion, order of resistance to antibiotics was bd $3 \mathrm{a}<$ buru $2<$ buru 1.

Azotobacter plays in important role for making fertilization in plant production more efficient and moreover detoxifing heavy metal in contaminated agricultural area. Azotobacter are renewable biological agent that does not require high production costs. Bioremediation of heavy-metal contaminated soil by bioaugmentation method by versatile Azotobacter is easy, safe, and cost effective.

\section{Acknowledgement}

Authors thank to Directorate General of Higher Education Indonesia for providing Basic Research Fund of year 2016.

\section{References}

Abo-Amer, A. E., Abu-gharbia, M. A., Soltan, E. M., \& Abd El-Raheem, W. M. (2014). Isolation and Molecular Characterization of Heavy Metal-Resistant Azotobacter chroococcum from Agricultural Soil and Their Potential Application in Bioremediation. Geomicrobiology journal, 31(7), 551-561. https://doi.org/10.1080/01490451.2013.850561

Akimenko, Y. V., Kazeev, K. S., Kolesnikov, S. I., Myasnikova, M. A., \& Minnikova, T. V. (2017). Assessing Resistance of the Microbial Community in Soils to Pollution with Antibiotics. Asian Journal of Pharmaceutics, 11(4), S798-S804. https://doi.org/10.22377/ajp.v11i04.1715 
Aleem, A., Isar, J., \& Mali, A. (2003). Impact of long-Term Application of Industrial Wastewater on The Emergence of Resistance Traits in Azotobacter chroococcum isolated from Rhizospheric Soil. Bioresource Technology, 86(1), Abstract. https://doi.org/10.1016/S0960-8524(02)00134-7

Aung, A., Yu, S. S., \& Sev, T. M. (2016). Development of Cellulolytic Nitrogen-Fixing Activity of Azotobacter spp. by Transposon Mutagenesis. Journal of Scientific and Innovative Research, 5(4), 130-134. http://www.jsirjournal.com/Vol5_Issue4_06.pdf

Cycoń, M., Mrozik, A., \& Piotrowska-Seget, Z. (2019). Antibiotics in the Soil Environment - Degradation and Their Impact on Microbial Activity and Diversity. Frontier in Microbiology, 10(Article 338). https://doi.org/10.3389/fmicb.2019.00338

Delcour, A. H. (2009). Membrane Permeability and Antibiotic Resistance. Biochimica et Biophysica Acta, 1794(5). 808-816. https://doi.org/10.1016/j.bbapap.2008.11.005

DeVries, S. L., \& Zhang, P. (2016). Antibiotics and the Terrestrial Nitrogen Cycle: A Review. Current Pollution Reports, 2, 51-67. https://doi.org/10.1007/s40726-016-0027-3

Faissal, A., Ouazzani, N., Parrado, J. R., Dary, M., Manyani, H., Morgado, B. R., ... Mandi, L. (2017). Impact of fertilization by natural manure on the microbial quality of soil: Molecular approach. Saudi Journal of Biological Science, 24(6), 1437-1443. https://doi.org/10.1016/j.sjbs.2017.01.005

Gaona, G., Núñez, C., Goldberg, J. B., Linford, A. S., Nájera, R., Castañeda, M., Guzmán, J., Espín, G., \& Soberón-Chávez, G. (2004). Characterization of The Azotobacter vinelandii algC Gene Involved in Alginate and Lipopolysaccharide Production. FEMS Microbiology Letters, 238(1), 199-206. https://doi.org/10.1016/j.femsle.2004.07.044

Geisinger, E., \& Isbe, R. R. (2015). Antibiotic Modulation of Capsular Exopolysaccharide and Virulence in Acinetobacter baumannii. PLoS Pathogen, 11(2), e1004691.

https://doi.org/10.1371/journal.ppat.1004691

Gupta, P., \& Diwan, B. (2016). Bacterial Exopolysaccharide Mediated Heavy Metal Removal: A Review on Biosynthesis, Mechanism and Remediation Strategies. Biotechnology Reports, https://doi.org/10.1016/j.btre.2016.12.006

Hindersah, R., Mulyani, O., \& Osok, R. (2017). Proliferation and Exopolysaccharide Production of Azotobacter in the Presence of Mercury. Biodiversity Journal, 8(1), 21-26 https://doi.org/10.15243/jdmlm.2018.052.1027

Hindersah, R., Risamasu, R., Kalay, A. M., Dewi, T., \& Makatita, I. (2018). Mercury Contamination in Soil, Tailing and Plants on Agricultural Fields Near Closed Gold Mine in Buru Island, Maluku. Journal of Degraded Mine and Land Management, 5(1), 1027-1034. https://doi.org/10.15243/jdmlm.2018.052.1027

Jorgensen, J. H., \& Ferraro, M. J. (2009). Antimicrobial Susceptibility Testing: A Review of General Principles and Contemporary Practices. Clinical Infectious Diseases, 49(11), 1749-1755. https://doi.org/10.1086/647952 
Masciandaro, G., Macci, C., Peruzzi, E., Ceccanti, B., \& Doni, S. (2013). Organic Matter-Microorganism-Plant in Soil Bioremediation: A Synergic Approach. Review on Environmental Science and Biotechnology, 12(4), 399-419.

https://doi.org/10.1007/s11157-013-9313-3

Massé, D. I., Saady, N. M., \& Gilbert, Y. (2014). Potential of Biological Processes to Eliminate Antibiotics in Livestock Manure: An Overview. Animals, 4(2), 146-163. https://doi.org/10.3390/ani4020146

Mus, F., Tseng, A., Dixon, R., \& Peters, J. W. (2017). Diazotrophic Growth Allows Azotobacter vinelandii to Overcome the Deleterious Effects of A glnE Deletion. Applied and Environmental Microbiology, 83, e00808-17. https://doi.org/10.1128/AEM.00808-17

Nakho, D., \& Dkhar, M. S. (2010). Impact of Organic and Inorganic Fertilizers on Microbial Populations and Biomass Carbon in Paddy Field Soil. Journal of Agronomy, 9(3), 102-110. https://doi.org/10.3923/ja.2010.102.110

Nanda, S., \& Abraham, J. (2011). Impact of Heavy Metals on The Rhizosphere Microflora of Jatropha multifida and Their Effective Remediation. African Journal of Biotechnology, 10(56), 11948-11955. DOI:10.5897/AJB10.1588

Opiso, F. M., Aseneiro, J. P. J., \& Banda, H. B. T. (2018). Solid-Phase Partitioning of Mercury in Artisanal Gold Mine Tailings from Selected Key Areas in Mindanao, Philippines, and Its Implications for Mercury Detoxification. Waste Management \& Research, 36(3), 269-276. https://doi.org/10.1177/0734242X17753534

Prasad, R. K., Gautam, R., \& Behal, S. (2014). Exopolysachharide Secreting Bacteria: Potential for Useful Applications. International Journal of Research, 1(1), 17-32.

www.internationaljournalofresearch.com

Rasulov, B. A., Yili, A., \& Aisa, H.A. (2011). Biosorption of Metal Ions by Exopolysaccharide Produced by Azotobacter chroococcum XU1. Journal of Environmental Protection, 4(9), 989-993. https://doi.org/10.4236/jep.2013.49114

Rizvi, A., \& Khan, M. S. (2018). Heavy Metal Induced Oxidative Damage and Root Morphology Alterations of Maize (Zea mays L.) Plants and Stress Mitigation by Metal Tolerant Nitrogen Fixing Azotobacter chroococcum. Ecotoxicological Environmental Safety, 157, 9-20. https://doi.org/10.1016/j.ecoenv.2018.03.063

Robson, R. L., Jones, R., Robson, R. M., Schwartz, A., \& Richardson, T. H. (2015). Azotobacter Genomes: The Genome of Azotobacter chroococcum NCIMB 8003 (ATCC 4412). PLoS ONE, 10(6), e0127997. https://doi.org/10.1371/journal.pone.0127997

Sabra, A., Zeng, P., Lonsdorf, H., \& Deckwer, W. D. (2000). Effect of Oxygen on Formation and Structure of Azotobacter vinelandii Alginate and Its Role in Producing Nitrogenase. Applied Environmental Microbiology, 66(9), 4037-4044.

https://doi.org/10.1128/AEM.66.9.4037-4044.2000 
Shinwari, K. I., Shah, A., Afridi, M. I., Zeeshan, M., Hussain, H., Hussain, J., Ahmad, O., \& Jamil, M. (2015). Application of Plant Growth Promoting Rhizobacteria in Bioremediation of Heavy Metal Polluted Soil. Asian Journal of Multidisciplinary Studies, 3(4), 179-185.

Sindhu, S. S., Grover, V., Narula, N., \& Lakshminarayana, K. (1989). Occurrence of Multiple Antibiotic Resistance in Azotobacter chroococcum. Zentralblatt fur Mikrobiologie, 144(2), 97-101. https://doi.org/10.1016/S0232-4393(89)80071-X

Sobariu, D. L., Fertu, D. I. T., Diaconu, M., Pavel, L. V., Hlihor, R. M., Drăgoi, E. N., Curteanu, S., Lenz, M., Corvini, P., \& Gavrilescu, M. (2017). Rhizobacteria and Plant Symbiosis in Heavy Metal Uptake and Its Implications for Soil Bioremediation. New Biotechnology, 39(Pt A), 125-134. https://doi.org/10.1016/j.nbt.2016.09.002

Widdel, F. (2010). Theory and Measurement of Bacterial Growth. [Online] file:///C:/Users/Reginawanti/Downloads/TheoryandMeasurementofBacterialGrowth.pdf (May 25, 2019).

Xie, W. Y., Shen, Q., \& Zhao, F. J. (2008). Antibiotics and Antibiotic Resistance from Animal Manures to Soil: A review. European Journal of Soil Science, 69(1), 181-195.

https://doi.org/10.1111/ejss.12494

\section{Copyright Disclaimer}

Copyright for this article is retained by the author(s), with first publication rights granted to the journal.

This is an open-access article distributed under the terms and conditions of the Creative Commons Attribution license (http://creativecommons.org/licenses/by/4.0/). 